\title{
Effect of LZSA Glass-Ceramic Addition on Pressureless Sintered Alumina. Part II: Mechanical Behavior
}

\author{
Oscar Rubem Klegues Montedo ${ }^{*}$, Pâmela Cabreira Milak ${ }^{a}$, Cristian Arnaldo Faller ${ }^{a}$, \\ Michael Peterson ${ }^{a}$, Agenor De Noni Junior ${ }^{a}$ \\ ${ }^{a}$ Universidade do Extremo Sul Catarinense - UNESC, Avenida Universitária, 1105, Criciúma, SC, Brazil
}

Received: January 06, 2017; Revised: August 19, 2017; Accepted: September 17, 2017

\begin{abstract}
This work aims to evaluate the influence of $\mathrm{Li}_{2} \mathrm{O}-\mathrm{ZrO}_{2}-\mathrm{SiO}_{2}-\mathrm{Al}_{2} \mathrm{O}_{3}(\mathrm{LZSA})$ glass-ceramic on the mechanical behavior of alumina. Composites were prepared from alumina with three different particle sizes and 7 to $21 \mathrm{vol} \%$ of an LZSA glass-ceramic composition $\left(11.6 \mathrm{Li}_{2} \mathrm{O}-16.8 \mathrm{ZrO}_{2}-68.2 \mathrm{SiO}_{2}-3.4 \mathrm{Al}_{2} \mathrm{O}_{3}\right.$, ). Specimens were obtained by uniaxial pressing. The optimum sintering temperature and holding time were found to be different for each composite. Structural characterization (bulk density and crystalline phases); mechanical characterization (flexure strength, elastic modulus, fracture toughness, and fracture energy); and microstructural analyses were carried out. Fine-grained alumina-based composite containing $21 \mathrm{vol} \%$ of glass-ceramic $\left(1470{ }^{\circ} \mathrm{C}\right.$ and $3 \mathrm{~h}$ holding time, $2.0 \%$ porosity) showed a fracture toughness of $4.93 \mathrm{MPa} \cdot \mathrm{m}^{0.5}$, an elastic modulus of $210 \mathrm{GPa}$, a fracture energy of $57 \mathrm{~J} \cdot \mathrm{m}^{-2}$, and a flexural strength of $170 \mathrm{MPa}$, in very good agreement with values reported by the literature. An increase of $37-177 \%$ in the fracture energy due to $21 \mathrm{vol} \%$ LZSA addition in the alumina was achieved for the range of grain size obtained in this work. Even though the final composition included a glassy component, the observed mechanical properties confirmed the effectiveness of the crystalline phases that were formed from LZSA glass-ceramic in reducing the propagation of cracks. The results showed that the addition of the LZSA glass-ceramic improved the mechanical properties of alumina.
\end{abstract}

Keywords: Alumina, LZSA glass-ceramic, composites, mechanical behavior

\section{Introduction}

Ceramic materials have been used to meet engineering requirements ${ }^{1}$, such as high wear-resistance in the power generation and aerospace industry ${ }^{2,3}$, because of their essential characteristics, such as chemical stability, fairly high hardness ${ }^{1-3}$, lower density when compared to metals ${ }^{2}$, high mechanical strength ${ }^{1,3}$, good refractory properties ${ }^{1-4}$, and high corrosion resistance ${ }^{2}$. Alumina is a typical engineering ceramic $^{1,5-7}$ used in structural applications ${ }^{7}$; automotive, aerospace, biomedical, and ballistic applications ${ }^{8}$; and cutting tools ${ }^{9}$.

Many studies have shown the influence of microstructure on the mechanical behavior of alumina, and most of them were focused on the effects of grain size ${ }^{10-17}$. A fine-grained microstructure ${ }^{3,10,11}$ and narrow range of particle size distribution often result in an improvement of the mechanical behavior of alumina ${ }^{10,11}$. For instance, similar relationships between wear rates and grain size are observed in various wear modes, such as erosive wear, abrasive wear, cutting, and grinding ${ }^{12}$. Moreover, the mechanical strength of alumina may be improved when the microstructure shows fine grainsize and residual porosity less than $0.05 \%{ }^{15}$.

Solid state sintering contributes to grain growth in alumina, because of the high temperatures and holding times

*e-mail: oscar.rkm@gmail.com applied. Thus, Liquid Phase Sintering (LPS) has emerged as a feasible alternative to obtain dense alumina with a refined microstructure and low porosity. The LPS application plays an important role in the processing of alumina, because the use of additives during this process allows the formation of a second phase that controls the grain growth phenomena. It seems that the erosive wear rate of LPS alumina is controlled by a combination of different features that may be related to grain size ${ }^{14}$. The types of glass that are most commonly used in LPS contain amorphous silica in their composition, which can degrade the mechanical behavior of the material ${ }^{18}$. Furthermore, the glassy phases are fragile and show low fracture toughness.

A reduction of the residual glassy phase can improve the mechanical behavior of alumina obtained by LPS. Thus, the use of a glass-such as a glass-ceramic-that encourages sintering during heating and also crystallizes in stable phases during the cooling cycle may be an alternative way to obtain highdensity alumina by LPS, while simultaneously producing a large amount of crystalline phase in the grain boundaries ${ }^{19}$. In addition, less grain growth and less residual glassy phase could be obtained.

The formed glass-ceramic must have a low coefficient of thermal expansion (CTE) in order to generate compressive residual stress at the interfaces with the alumina. This stress should strengthen the structure, hampering the stripping of 
alumina grains and improving the mechanical performance of the material. Among the several known glass-ceramic systems, $\mathrm{LZSA}\left(\mathrm{Li}_{2} \mathrm{O}-\mathrm{ZrO}_{2}-\mathrm{SiO}_{2}-\mathrm{Al}_{2} \mathrm{O}_{3}\right)$ crystallizes mostly as $\beta$-spodumene ss $_{\text {s }}$ (solid solution, $\mathrm{Li}_{2} \mathrm{O} \cdot \mathrm{Al}_{2} \mathrm{O}_{3} \cdot 4-10 \mathrm{SiO}_{2}$ ) and zirconium silicate $\left(\mathrm{ZrSiO}_{4}\right)^{20-22}$, allowing the fabrication of materials with a low CTE (ranging from 5.1 to $5.3 \times 10^{-6}{ }^{\circ} \mathrm{C}^{-1}$, over the range of 25 to $\left.325^{\circ} \mathrm{C}\right)^{20}$. The high crystallinity, low porosity, and fine microstructure (crystal sizes of $1 \mu \mathrm{m}$ ) that are obtained $\mathrm{d}^{21-22}$ result in high wear resistance and flexural strength $^{23}$. Moreover, LZSA shows surface crystallization and achieves high densification at lower temperatures: above $95 \%$ in the range of 630 to $770{ }^{\circ} \mathrm{C}^{22,24}$.

Alumina-based composites have been studied in order to achieve high performance materials ${ }^{4-6,8}$, and it was found that the introduction of a second crystalline phase to improve the properties of alumina, such as fracture toughness, plays an important role. In fact, Montedo et al. ${ }^{25}$ studied the effect of the LZSA $\left(11.6 \mathrm{Li}_{2} \mathrm{O}-16.8 \mathrm{ZrO}_{2}-68.2 \mathrm{SiO}_{2}-3.4 \mathrm{Al}_{2} \mathrm{O}_{3}\right)$ glassceramic on the grain growth of alumina. The addition of $21 \mathrm{vol} \%$ LZSA to fine alumina $\left(\mathrm{d}_{50}=0.5 \mu \mathrm{m}\right)$ enabled the lowering of the sintering temperature from 1600 to 1470 ${ }^{\circ} \mathrm{C}$, and the holding time from $10 \mathrm{~h}$ to $40 \mathrm{~min}$, for the same relative density.

Thus, Part II of this work aims to evaluate the effect on the mechanical behavior of alumina caused by the addition of an LZSA glass-ceramic.

\section{Experimental}

Five compositions were prepared from an LZSA glassceramic composition (Tecnofrita, Brazil) and three grades of alumina ( $99.8 \mathrm{wt} \%$ of $\mathrm{Al}_{2} \mathrm{O}_{3}$, Almatis, USA); the chemical composition, particle size, and specific surface area of these materials were presented in the previous work ${ }^{25}$. The experimental design used two factors: the particle size of alumina and the glass-ceramic content varied on two levels $(-1$ and +1$)$. A full factorial design $2^{2}$ was established with three central points. The variation ranges of the factors are shown in Table 1. The description $A_{i}$ is related to the particle size of alumina, where $A_{F}$ is the fine alumina, $A_{M}$ is the medium alumina, and $A_{C}$ is the coarse alumina. The number next to this description refers to the glass-ceramic content. Compositions were wet-mixed (with $0.1 \mathrm{wt} \%$ sodium tripolyphosphate as dispersant, $1.0 \mathrm{wt} \%$ carboxymethylcellulose as plastifier, and $1.5 \mathrm{wt} \%$ polyvinyl alcohol as binder) and dried in a spray-dryer (LabMaq do Brasil Ltda LM MSD 1.0 , Brazil) to obtain powders ( $8 \mathrm{wt} \%$ water). The powders were formed by uniaxial pressing (Gabbrielli GT 0785, Italy) at $128 \mathrm{MPa}$ specific pressure with a green density ranging from 1.92 to $2.61 \mathrm{~g} \cdot \mathrm{cm}^{-3}$, (i.e., 50.9 to $65.4 \%$ of theoretical density) depending on the LZSA content, and dried at $110 \pm$ $5{ }^{\circ} \mathrm{C}$. The sintering temperature was measured by an optical dilatometer (Expert System Solutions S.R.L Misura HSM ODHT 1400, Italy); and the temperature cycle included a
Table 1. Experimental design with the combinations among each factor.

\begin{tabular}{cccccc}
\hline \multirow{2}{*}{$\begin{array}{c}\text { Material } \\
\text { code }\end{array}$} & $\begin{array}{c}\mathbf{d}_{\mathbf{5 0}}(\boldsymbol{\mu} \boldsymbol{\mu m}) \\
\text { of } \\
\text { alumina }\end{array}$ & \multicolumn{2}{c}{ LZSA } & \multicolumn{3}{c}{$\begin{array}{c}\text { Sintering } \\
\text { conditions }\end{array}$} \\
\cline { 3 - 6 } & $\mathbf{( v o l \% )}$ & $\mathbf{( w t \% )}$ & $\mathbf{T}$ ( $\left.\mathbf{}^{\mathbf{O}} \mathbf{C}\right)$ & $\mathbf{t}(\mathbf{h})$ \\
\hline $\mathrm{A}_{\mathrm{F}}$ & 0.5 & 0 & 0 & 1600 & 4 \\
$\mathrm{~A}_{\mathrm{M}}$ & 1.7 & 0 & 0 & 1600 & 7 \\
$\mathrm{~A}_{\mathrm{C}}$ & 2.8 & 0 & 0 & 1600 & 10 \\
$\mathrm{~A}_{\mathrm{F}} 7$ & 0.5 & 7 & 5 & 1600 & 4 \\
$\mathrm{~A}_{\mathrm{C}} 7$ & 2.8 & 7 & 5 & 1600 & 7 \\
$\mathrm{~A}_{\mathrm{F}} 21$ & 0.5 & 21 & 15 & 1470 & 3 \\
$\mathrm{~A}_{\mathrm{C}} 21$ & 2.8 & 21 & 15 & 1600 & 0.67 \\
$\mathrm{~A}_{\mathrm{M}} 15-1$ & 1.7 & 15 & 10 & 1600 & 3 \\
$\mathrm{~A}_{\mathrm{M}} 15-2$ & 1.7 & 15 & 10 & 1600 & 3 \\
$\mathrm{~A}_{\mathrm{M}} 15-3$ & 1.7 & 15 & 10 & 1600 & 3 \\
\hline
\end{tabular}

$1{ }^{\circ} \mathrm{C} \cdot \mathrm{min}^{-1}$ heating rate, $90 \mathrm{~min}$ holding times at 1100 and $1300{ }^{\circ} \mathrm{C}$, and a $1600{ }^{\circ} \mathrm{C}$ maximum temperature). Sintering temperatures and holding times are shown in Table 1 . The compacted alumina and the composites were sintered in an electrical kiln (Fortelab ME 1700/10, Brazil). Controlled cooling $\left(10^{\circ} \mathrm{C} \cdot \mathrm{min}^{-1}\right.$ cooling rate, $30 \mathrm{~min}$ holding time at $760{ }^{\circ} \mathrm{C}, 10^{\circ} \mathrm{C} \cdot \mathrm{min}^{-1}$ cooling rate up to room temperature) was carried out in order to form crystalline phases in the glass-ceramic. Porosities were calculated from $d_{r e l}$; the values of which were published by Montedo et $a .^{25}$. The flexural strength (FS) of the sintered samples was determined based on ASTM 1161-02 using a mechanical testing machine (EMIC DL10000, Brazil). The elastic modulus was determined in a transitory vibration analyzer (ATCP Engenharia Física Sonelastic, Brazil). Fracture toughness measurements $\left(\mathrm{K}_{\mathrm{IC}}\right)$ were performed using the notch method (Single Edged Notched Beam, SENB), which consists of making a notch in the specimen by means of a diamond cutting disk $(0.8$ $\mathrm{mm}$ thickness, $0.5 \mathrm{~mm}$ pitch). The depth of the notch was equal to $40 \%$ of the total thickness of the specimen. Then the specimens were submitted to flexure in a mechanical testing machine (EMIC DL10000, Brazil). The value of $\mathrm{K}_{\mathrm{IC}}$ was calculated by the Griffith equation:

$$
K_{I C}=\sigma \cdot Y \cdot \sqrt{a}
$$

where $\sigma$ is the rupture stress, $Y$ is the calibration factor and / is the depth of the notch (or the natural flaw).

The calibration factor for this type of notch is given by Eq. 2, where $b$ is the width of the specimen.

$$
\begin{aligned}
& Y=1.99-2.47\left(\frac{a}{b}\right)+12.97\left(\frac{a}{b}\right)^{2}- \\
& 23.17\left(\frac{a}{b}\right)^{3}+24.8\left(\frac{a}{b}\right)^{4}
\end{aligned}
$$

From the data of $\mathrm{K}_{\mathrm{IC}}$ and FS measurements, the natural flaw size, $a$, may be calculated from Griffith equation. 
According to the theory of fracture mechanics, one can obtain the fracture energy $(\gamma)$ of the material from Eq. 3, where $E$ is the elastic modulus.

$$
K_{I C}=\sqrt{2 \cdot E \cdot \gamma}
$$

Five specimens of each condition were used for measurements of mechanical properties.

The residual stress resulting from the interaction between alumina and LZSA was obtained by X-ray diffractometry (Shimadzu XRD-6000, Japan; radiation $\mathrm{CuK} \alpha, 0.02^{\circ}$ step) by means of the evaluation of the displacement in the $2 \theta$ angle of the highest $\alpha$-alumina peak (Bragg's law, $57.47^{\circ}$ (116), JCPDS card number 42-1468). The microstructure of the sintered samples was evaluated by scanning electron microscopy (SEM, Zeiss EVO MA10, Germany). Fractured samples were used to assess the interaction between the alumina and the glass-ceramic. Specimens were etched in 2 vol\% HF for $25 \mathrm{~s}$ and coated with a thin Au film. This chemical etch was carried out to eliminate the glass-ceramic existing on the surface of the samples and thereby allow the visualization of the grain morphology and particles.

\section{Results and Discussion}

Part I of this work demonstrated the effect of an LZSA glass-ceramic on the grain growth of alumina ${ }^{25}$, since the grain size is one of the most important microstructural features that must be controlled in order to obtain high performance alumina. Microstructural control by means of dopants and processing techniques can improve the mechanical properties of alumina-wear for example ${ }^{16}$. Thus, suppression of grain growth plays a crucial role.

In this Part II, LZSA glass-ceramic was added to alumina to cause suppression of grain growth; however, crystalline phases were formed during heating in the range of $640-820{ }^{\circ} \mathrm{C}^{19}$.

Because the composites were sintered at higher temperatures $\left(>1450^{\circ} \mathrm{C}\right)$, those crystalline phases were dissolved into the glassy phase after the melting of the LZSA. Nevertheless, after sintering, the controlled cooling of composites allowed the crystallization of LZSA. In fact, Figure 1 shows that $\beta$-spodumene ss $_{\text {s }}\left(\mathrm{Li}_{0-6} \mathrm{Al}_{0-6} \mathrm{Si}_{2-4} \mathrm{O}_{6}\right.$, JCPDS No. 21-503, and $\mathrm{LiAlSi}_{3} \mathrm{O}_{8}, \mathrm{JCPDS}$ No. 15-27), zirconium oxide $\left(\mathrm{ZrO}_{2}\right.$, JCPDS No. 13-307), and quartz ( $\mathrm{SiO}_{2}$, JCPDS No. 5-490) were formed during the controlled cooling of composite $A_{F} 21$. Those crystalline phases caused the formation of compressive stress at the alumina/glass-ceramic interface as confirmed by the displacement of the main alumina peak in the XRD patterns ${ }^{19}$.

Figure 2 shows the elastic modulus (E) of the alumina ceramics and composites that were investigated in this study, as a function of the LZSA content. One may observe that $\mathrm{E}$ shows an inversely proportional behavior in relation

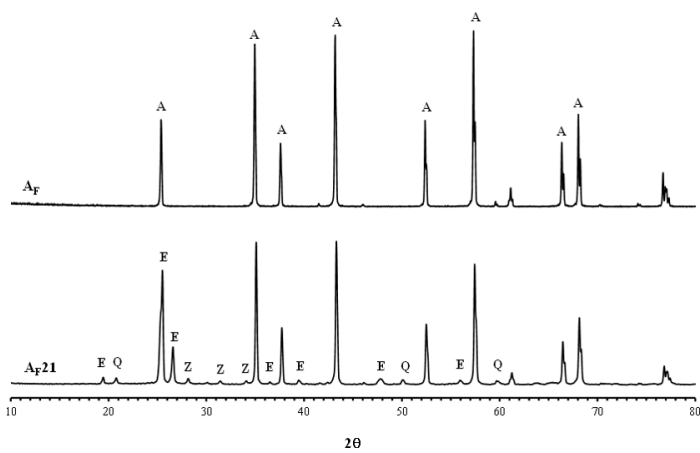

Figure 1. XRD patterns of alumina $A_{F}$ and composite $A_{F} 21$. A: $\mathrm{Al}_{2} \mathrm{O}_{3}, \mathrm{E}: \beta$-spodumene ${ }_{\mathrm{ss}}$, Q: quartz $\left(\mathrm{SiO}_{2}\right), \mathrm{Z}: \mathrm{ZrO}_{2}$. Alumina $\mathrm{A}_{\mathrm{F}}$ was sintered at $1600^{\circ} \mathrm{C}$ ( 30 min holding time) while composite $\mathrm{A}_{\mathrm{F}} 21$ was sintered at $1470{ }^{\circ} \mathrm{C}$ ( $3 \mathrm{~h}$ holding time) and summited to controlled cooling at $7600^{\circ} \mathrm{C}$ (30 min holding time).

to porosity. The maximum value in the E-LZSA content plot was obtained at $7 \mathrm{vol} \%$ LZSA $\left(94.8 \% \mathrm{Al}_{2} \mathrm{O}_{3}\right.$ purity) regardless of the amount of alumina used (porosity of 5.1 and $4.1 \%$ for $\mathrm{A}_{\mathrm{F}} 7$ and $\mathrm{A}_{\mathrm{C}} 7$, respectively). However, at higher LZSA contents $E$ diminishes probably because of the poor distribution of LZSA into the bulk of alumina. Terheci ${ }^{26}$ obtained higher $\mathrm{E}$ values for pure alumina compositions (386 GPa, $1600{ }^{\circ} \mathrm{C} / 30$ min holding time), while $\mathrm{Munro}^{27}$ obtained $416 \pm 30 \mathrm{GPa}$ for $99.5 \%$ purity $\mathrm{Al}_{2} \mathrm{O}_{3}$ sintered at $1700{ }^{\circ} \mathrm{C}$ and showing $5-\mu \mathrm{m}$ grain size and $2.0 \%$ porosity; the value of $\mathrm{E}$ decreased for longer sintering holding times. For the types of alumina used in this study, alumina particle size had no significant effect on the E values for the LZSA compositions that were investigated.

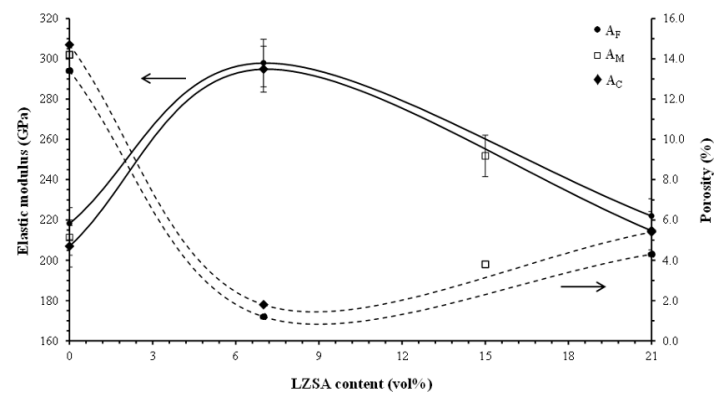

Figure 2. Elastic modulus (E) and porosity in function of the LZSA content of the alumina ceramics and LZSA/alumina composites.

Figure 3 shows $\mathrm{K}_{\mathrm{IC}}$ results for the alumina ceramics and composites. The LZSA addition increased $\mathrm{K}_{\mathrm{IC}}$ regardless of the alumina particle size used in this work. The $\mathrm{K}_{\mathrm{IC}}$ values were found to be $4.24,4.93,3.9$, and $4.6 \mathrm{MPa} \cdot \mathrm{m}^{0.5}$ for $\mathrm{A}_{\mathrm{F}} 7$, $\mathrm{A}_{\mathrm{F}} 21, \mathrm{~A}_{\mathrm{C}} 7$, and $\mathrm{A}_{\mathrm{C}} 21$, respectively. Taking into account the obtained standard deviation, one can say that there is no difference between these $\mathrm{K}_{\mathrm{IC}}$ values, although one can observe a tendency of $\mathrm{K}_{\mathrm{IC}}$ increasing for higher values of LZSA content and lower particle sizes. Lube et al. ${ }^{28}$ obtained 
$3.8 \mathrm{MPa} \cdot \mathrm{m}^{0.5}$, while Marques ${ }^{29}$ cited $\mathrm{K}_{\mathrm{IC}}$ values ranging from 3.85 to $3.95 \mathrm{MPa} \cdot \mathrm{m}^{0.5}$ for sintered alumina (relative density of $99.5 \%$ ). Tuan et al. $^{30}$ found $5.0 \mathrm{MPa} \cdot \mathrm{m}^{0.5}$ for sintered alumina ( $1.7 \%$ porosity, $13.3-\mu \mathrm{m}$ grain size), and $\mathrm{Wu}$ et al. ${ }^{18}$ found $3.6 \mathrm{MPa} \cdot \mathrm{m}^{0.5}$ for pure alumina and $4.8 \mathrm{MPa}$. $\mathrm{m}^{0.5}$ for LPS alumina. Therefore, even though composites $\mathrm{A}_{\mathrm{F}} 7, \mathrm{~A}_{\mathrm{F}} 21, \mathrm{~A}_{\mathrm{C}}$, and $\mathrm{A}_{\mathrm{C}} 21$ had glass in their composition, they showed $\mathrm{K}_{\mathrm{IC}}$ values larger than those for pure alumina reported for the literature, confirming the effectiveness of the crystalline phases formed from LZSA glass-ceramic to reduce the crack propagation.

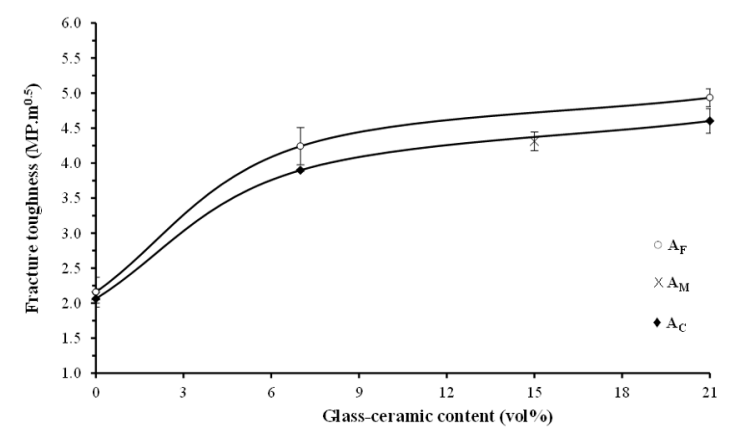

Figure 3. Fracture toughness in function of the LZSA content of the alumina ceramics and LZSA/alumina composites.

Fracture energy $(\gamma)$ was calculated from the data of $\mathrm{K}_{\mathrm{IC}}$ and $\mathrm{E}$, using Eq. 3. Figure 4 shows the effect of LZSA content on the fracture energy of alumina. Fracture energy increased with increasing LZSA content for the investigated composites. This effect may be attributed to the alumina/LZSA interaction and the obtained microstructures, in particular, the increase of roughness. However, it is important to emphasize that pure alumina $\left(\mathrm{A}_{\mathrm{F}}, \mathrm{A}_{\mathrm{M}}\right.$, and $\left.\mathrm{A}_{\mathrm{C}}\right)$ were sintered at the same temperature as the composites, i.e. $1600^{\circ} \mathrm{C}$, and because of this, the obtained relative densities were much lower than that of dense alumina. Nevertheless, fracture energy data of alumina with very similar grain sizes and porosities in relation to the investigated composites were obtained from National Institute of Standards and Technology - NIST ${ }^{31}$, as shown in Table 2. Table 2 shows that the fracture energy ranges from 18.0 to $36.5 \mathrm{~J} \cdot \mathrm{m}^{-2}$ for alumina similar to that used in this work. Taking into account that the grain size obtained in this work ranged from $\sim 1$ to $12 \mu \mathrm{m}$, one may say that the addition of LZSA glass-ceramic increased the fracture energy of alumina up to $50 \mathrm{~J} \cdot \mathrm{m}^{-2}(21 \mathrm{vol} \% \mathrm{LZSA}$ addition), which represents an increase of $37-177 \%$.

Figure 5 shows images (photographies) of composites $\mathrm{A}_{\mathrm{F}} 7, \mathrm{~A}_{\mathrm{F}} 21, \mathrm{~A}_{\mathrm{C}} 7$, and $\mathrm{A}_{\mathrm{C}} 21$. The textures of the composites containing 7 and 21 vol\% of LZSA are quite different from each other. One can see that the 21-vol\% based-composites $\left(A_{F} 21\right.$ and $\left.A_{C} 21\right)$ are much rougher than the 7-vol\% basedcomposites $\left(A_{F} 7\right.$ and $\left.A_{C} 7\right)$. The rougher the material, the greater the contact between particles; consequently, more

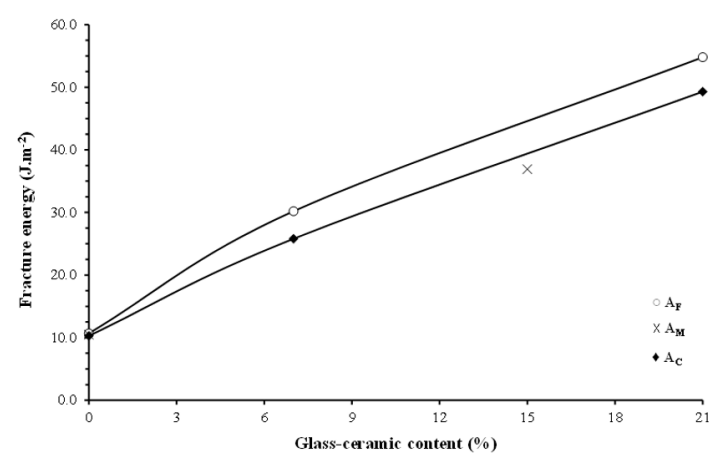

Figure 4. Fracture energy of composites.

Table 2. Fracture energy data from NIST.

\begin{tabular}{ccccc}
\hline $\begin{array}{c}\text { Material } \\
\text { designation }\end{array}$ & $\begin{array}{c}\mathbf{A l}_{\mathbf{2}} \mathbf{O}_{\mathbf{3}} \text { content } \\
(\mathbf{w t} \%)\end{array}$ & $\begin{array}{c}\text { Grain } \\
\text { size }(\boldsymbol{\mu \mathbf { m } )})\end{array}$ & $\begin{array}{c}\text { Porosity } \\
\mathbf{( \% )}\end{array}$ & $\begin{array}{c}\text { Fracture } \\
\text { energy } \\
\left(\mathbf{J} . \mathbf{m}^{-2}\right)\end{array}$ \\
\hline Lucalox $^{31}$ & 99.9 & 10 & - & 18.0 \\
Lucalox-HS $^{32}$ & 99.9 & $6-10$ & - & 18.0 \\
$\mathrm{AD}^{2} 999^{33}$ & 99.9 & 3 & - & 24.3 \\
$\mathrm{XA16}^{34}$ & 99.9 & 0.53 & 10 & 11.7 \\
& & 0.89 & 6 & 26.8 \\
& & 1.3 & 5 & 31.4 \\
& & 1.9 & 2.5 & 25.5 \\
& & 3.3 & 5 & 22.6 \\
& & 3.7 & 2.0 & 36.3 \\
& & 4.1 & 5 & 23.8 \\
& & 5.0 & 1.2 & 36.5 \\
& & 7.2 & 1.0 & 31.1 \\
\hline
\end{tabular}

energy is necessary to break bonds. On the other hand, the roughness should also have contributed to the reduced $\mathrm{E}$ values obtained for $\mathrm{A}_{\mathrm{F}} 21$ and $\mathrm{A}_{\mathrm{C}} 21$. Binns and Popper ${ }^{32}$ found energy fracture values of $30 \mathrm{~J} \cdot \mathrm{m}^{-2}\left(95.6 \% \mathrm{Al}_{2} \mathrm{O}_{3}\right.$ purity, $5-\mu \mathrm{m}$ grain size, $2 \%$ porosity) and $53 \mathrm{~J} \cdot \mathrm{m}^{-2}\left(97.3 \% \mathrm{Al}_{2} \mathrm{O}_{3}\right.$ purity, $30-\mu \mathrm{m}$ grain size, $5 \%$ porosity). Thus, composites $\mathrm{A}_{\mathrm{F}} 21$ and $\mathrm{A}_{\mathrm{C}} 21$ could be used for some applications where high impact resistance is required in addition to wear resistance.

Composites $A_{F} 7$ and $A_{C} 7$ showed higher flexural strength (FS) values than alumina $A_{F}, A_{M}$, and $A_{C}$, as shown in Figure 6. Sathinyakumar and Gnanam ${ }^{33}$ obtained 119 MPa for pure alumina sintered at $1400{ }^{\circ} \mathrm{C}$, while Goswami and $\operatorname{Das}^{34}$ obtained $288 \mathrm{MPa}$ for LPS alumina, just slightly higher than the highest value found in this study (273 MPa for composite $\left.A_{F} 7\right)$. With the increase of LZSA content, the FS value decreased, probably due to the increase of the natural defect size $(a)$, obtained from Eq. 1, of the composites (Figure 7). By comparison, Figures 6 and 7 show that FS is higher for lower values of natural defect size. Figure 7 shows that $a$ increased with the increase of alumina particle size and LZSA content. However, these effects tend to be insignificant at higher LZSA contents $(\sim 21$ vol\%). Alumina 

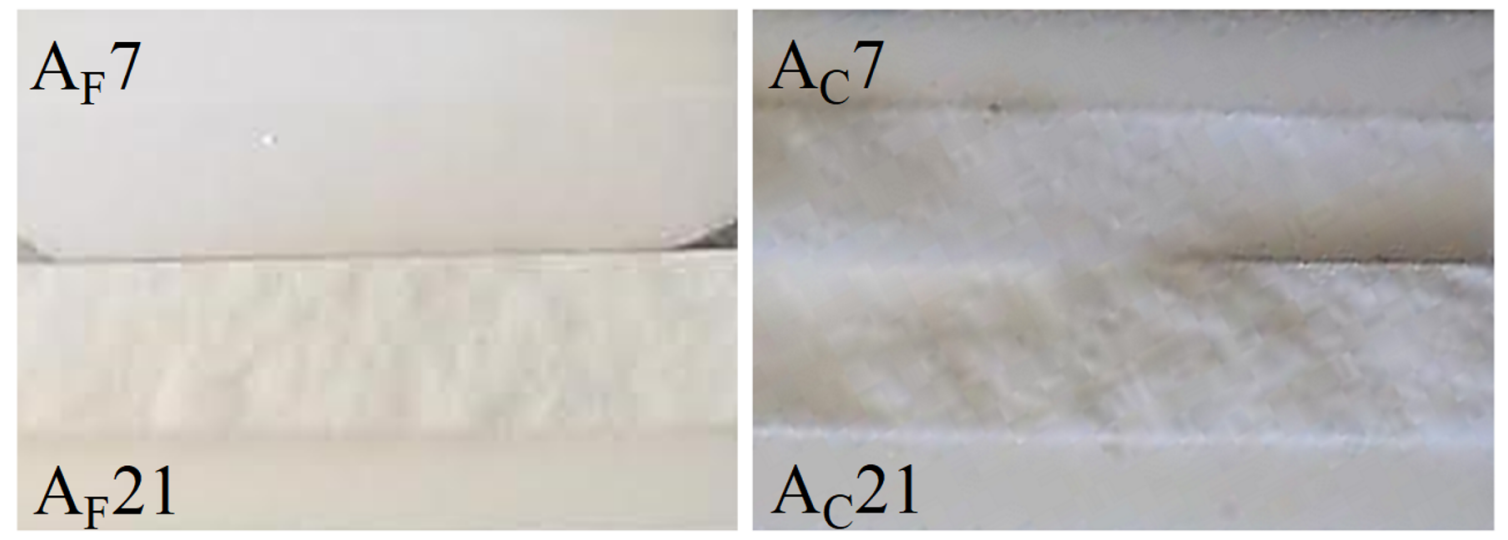

Figure 5. Images (photographies) showing the texture of composites $A_{F} 7, A_{F} 21, A_{C} 7$ and $A_{C} 21$.

particle size seems to be the main factor that determined the sizes of the natural defects in the samples with up to $7 \mathrm{vol} \%$ LZSA. On the other hand, the addition of $21 \mathrm{vol} \% \mathrm{LZSA}$ (composites $\mathrm{A}_{\mathrm{F}} 21$ and $\mathrm{A}_{\mathrm{C}} 21$ ) increased the natural defect size for all investigated alumina. It is possible that the residual vitreous phase in these composites has increased the natural defect size, as reported by De Noni et al. ${ }^{35}$.

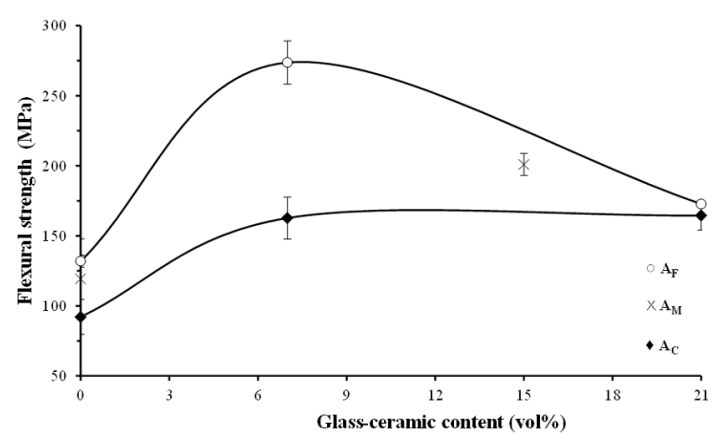

Figure 6. Flexural strength in function of LZSA content of the alumina ceramics and LZSA/alumina composites.

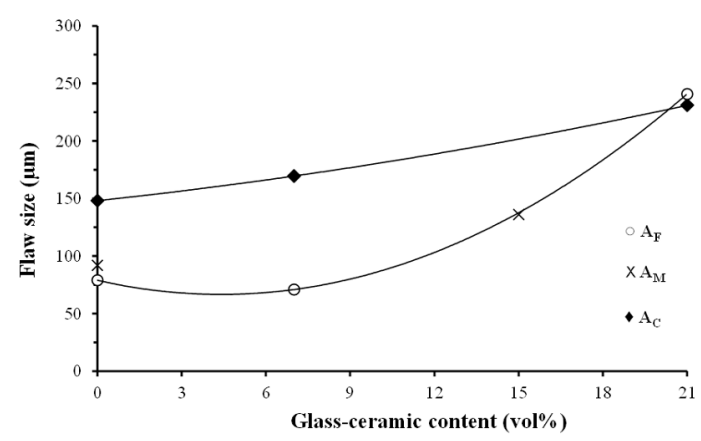

Figure 7. Calculated natural defect size in function of LZSA content of the alumina ceramics and LZSA/alumina composites.

As mentioned before, LZSA glass-ceramic was added to alumina in order to generate residual stress and improve the mechanical properties. Figure 8 presents the XRD patterns of composites $A_{F}, A_{F} 7$, and $A_{F} 21$. Peak displacement occurred toward the left side of the XRD patterns; the higher the LZSA content, the higher the displacement. This displacement demonstrates the existence of compressive residual stresses that were caused by the lower coefficient of thermal expansion of LZSA $\left(5.2 \times 10^{-6}{ }^{\circ} \mathrm{C}^{-1}\right)^{20}$ in comparison to alumina (8.1 $\left.\times 10^{-6}{ }^{\circ} \mathrm{C}^{-1}\right)$. The other composites also showed the same behavior. Figure 8 also shows that the peak displacement was higher for composite $A_{F} 21$ than for composite $A_{C} 21$, possibly due to the greater specific surface area of the former; and consequently, the greater interface region between the alumina and the LZSA. Thus, the interaction between fine alumina $\left(\mathrm{A}_{\mathrm{F}}\right)$ and the LZSA may help to explain the mechanical behavior of the investigated composites.

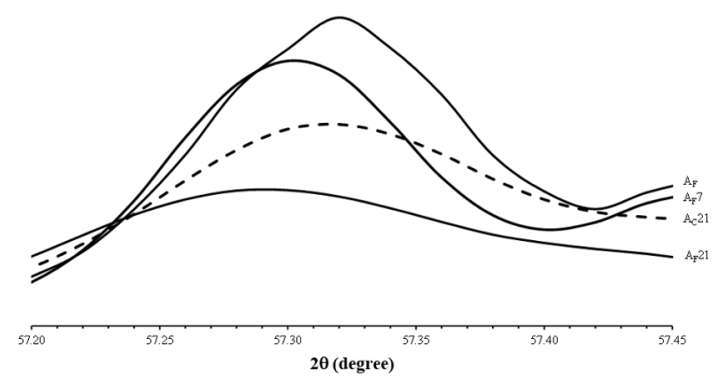

Figure 8. Partial XRD patterns of the alumina $A_{F}$ and composites $A_{F} 7, A_{F} 21$ and $A_{C} 21$.

Figure 9 shows SEM observations of fractured specimens of the alumina ceramics and composites. LZSA is homogeneously dispersed in all the specimens, as detailed in Figure 10. It seems as if the microstructure of composites $A_{M} 15$ and $A_{C} 21$ are quite similar, which could explain the similarity in their mechanical properties.

The LZSA addition also changed the morphology of the alumina, as shown in Figure 11 for the etched specimens. The morphology is influenced by the chemical composition of the intergranular phase of materials obtained by LPS and can significantly change the mechanical properties of alumina ${ }^{36-38}$. As shown in the SEM observations, the composites have 

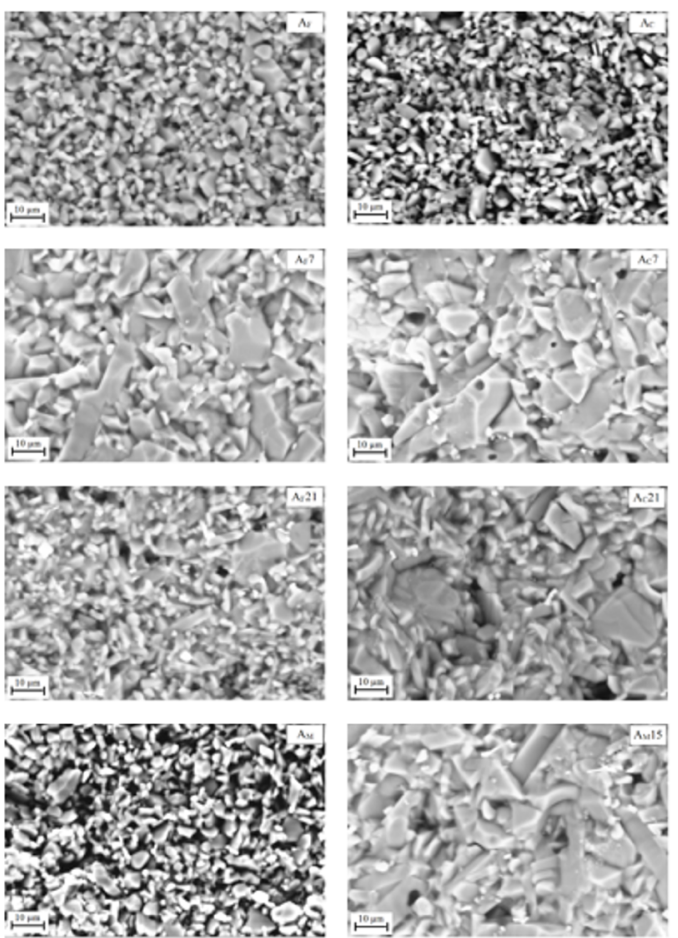

Figure 9. SEM observations of the alumina ceramics and LZSA/ alumina composites: fractured specimens.

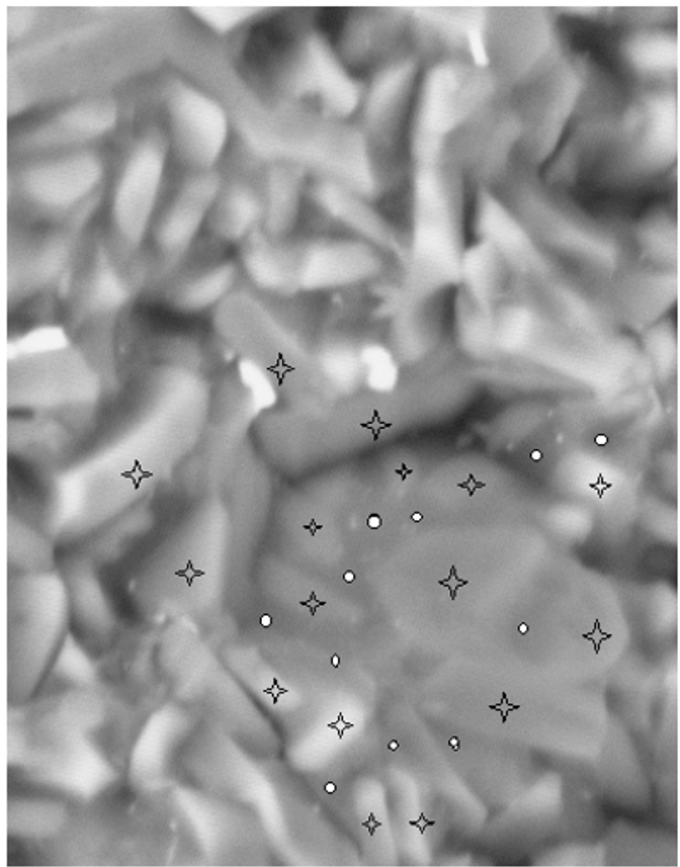

Figure 10. Detail of the fractured composite $A_{c} 21: \&$ alumina and $\circ$ LZSA glass-ceramic.

elongated grains. Elongated grains can act as reinforcement material in the microstructure and indeed contribute to the increased fracture toughness ${ }^{36,38}$. Composite $\mathrm{A}_{\mathrm{F}} 21$ achieved a high relative density at a lower temperature $\left(1470{ }^{\circ} \mathrm{C}\right)$;
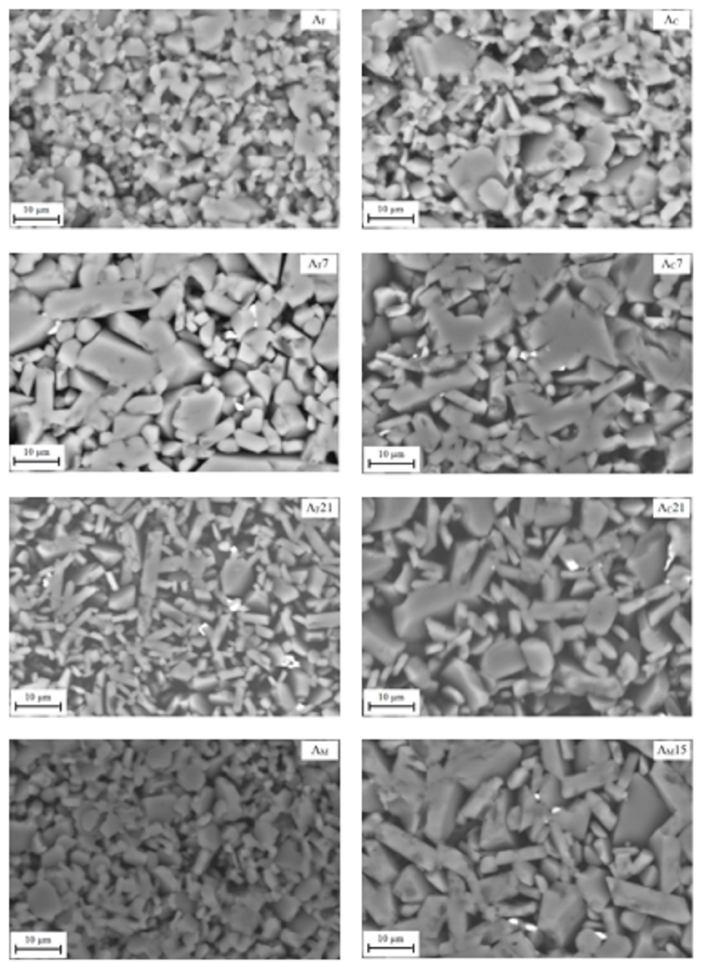

Figure 11. SEM observations of the alumina ceramics and LZSA/ alumina composites: etched specimens.

and because of this, alumina grains did not experience as much growth. In fact, sintering at lower temperatures in the presence of the liquid phase may cause a suppression of grain growth ${ }^{38}$. Although composites $\mathrm{A}_{\mathrm{F}} 7$ and $\mathrm{A}_{\mathrm{C}} 7$ show the presence of elongated grains, one can also see coarse, equiaxed grains.

\section{Conclusions}

The influence of LZSA $\left(\mathrm{Li}_{2} \mathrm{O}-\mathrm{ZrO}_{2}-\mathrm{SiO}_{2}-\mathrm{Al}_{2} \mathrm{O}_{3}\right)$ glassceramic on the mechanical behavior of alumina was investigated. Liquid phase sintering promoted higher densification than the use of pure alumina. A composite containing fine grain alumina and $21 \mathrm{vol} \%$ of glass-ceramic sintered at $1470{ }^{\circ} \mathrm{C}$ ( $3 \mathrm{~h}$ holding time) showed lower porosity $(2 \%)$ than pure alumina sintered at $1600{ }^{\circ} \mathrm{C}(5 \%)$. The initial particle size of alumina had little influence on the mechanical properties; however, the glass-ceramic addition caused a significant effect on the mechanical properties. Elongated grains of alumina were observed in the composites as a result of glass-ceramic addition, which caused strengthening of the structure and improved the fracture toughness. Fine-grained alumina-based composite containing $21 \mathrm{vol} \%$ of glass-ceramic $\left(1470{ }^{\circ} \mathrm{C}\right.$ and $3 \mathrm{~h}$ holding time, $2 \%$ porosity) showed a fracture toughness of $4.93 \mathrm{MPa} \cdot \mathrm{m}^{0.5}$, elastic modulus of $210 \mathrm{GPa}$, fracture energy of $57 \mathrm{~J} \cdot \mathrm{m}^{-2}$, and flexural strength of $170 \mathrm{MPa}$, in very good agreement with values reported in the literature. Thus, the introduction of a liquid phase in the sintering of alumina, 
which crystallizes during controlled cooling, i.e. the use of a glass-ceramic, allowed us to modify significantly the microstructure of alumina, and consequently, the mechanical properties. The results showed that the addition of the LZSA glass-ceramic improved the mechanical properties of alumina.

\section{Acknowledgements}

The authors are very grateful to Conselho Nacional de Desenvolvimento Científico e Tecnológico (CNPq/Brazil) and Financiadora de Estudos e Projetos (FINEP/Brazil) for funding this study.

\section{References}

1. Medvedovski E. Wear-resistant engineering ceramics. Wear. 2001;249(9):821-828. DOI: 10.1016/S0043-1648(01)00820-1

2. Zhou J, Bahadur S. Erosion characteristics of alumina ceramics at high temperatures. Wear. 1995;181-183(Pt 1):178-188. DOI: 10.1016/0043-1648(95)90022-5

3. Zhang Y, Cheng YB, Lathabai S. Erosion of alumina ceramics by air- and water-suspended garnet particles. Wear. 2000;240(12):40-51. DOI: 10.1016/S0043-1648(00)00335-5

4. Zhang FC, Luo HH, Wang TS, Roberts SG, Todd RI. Influence factors on wear resistance of two alumina matrix composites. Wear. 2008;265(1-2):27-33. DOI: 10.1016/j.wear.2007.08.011

5. Puchy V, Hvizdos P, Dusza J, Kovac F, Inam F, Reece MJ. Wear resistance of $\mathrm{Al}_{2} \mathrm{O}_{3}-\mathrm{CNT}$ ceramic nanocomposites at room and high temperatures. Ceramics International. 2013;39(5):58215826. DOI: 10.1016/j.ceramint.2012.12.100

6. Cesari F, Esposito L, Furgiuele FM, Maletta C, Tucci A. Fracture thoughness of alumina-zirconia composites. Ceramics International. 2006;32(3):249-255. DOI: 10.1016/j.ceramint.2005.02.012

7. Medvedovski E. Alumina-mullite ceramics for structural applications. Ceramics International. 2006;32(4):369-375. DOI: 10.1016/j.ceramint.2005.04.001

8. Silva MV, Stainer D, Al-Qureshi HA, Montedo ORK, Hotza D. Alumina-Based Ceramics for Armor Application: Mechanical Characterization and Ballistic Testing. Journal of Ceramics. 2014;2014:618154. DOI: 10.1155/2014/618154

9. Kumar AS, Durai AR, Sornakumar T. Wear behaviour of alumina based ceramic cutting tools on machining steels. Tribology International. 2006;39(3):191-197. DOI: 10.1016/j. triboint.2005.01.021

10. Cho SJ, Hockey BJ, Lawn BR, Bennison SJ. Grain-Size and R-Curve Effects in the Abrasive Wear of Alumina. Journal of the American Ceramic Society. 1989;72(7):1249-1252. DOI: 10.1111/j.1151-2916.1989.tb09718.x

11. Mukhopadhyay AK, Mai YW. Grain size effect on abrasive wear mechanisms in alumina ceramics. Wear. 1993;162-164(Pt A):258-268. DOI: 10.1016/0043-1648(93)90508-J

12. Miranda-Martinez M, Davidge RW, Riley FL. Grain size effects on the wet erosive wear of high-purity polycrystalline alumina. Wear. 1994;172(1):41-48. DOI: 10.1016/0043-1648(94)90297-6
13. Davidge RW, Riley FL. Grain-size dependence of the wear of alumina. Wear. 1995;186-187(Pt 1):45-49. DOI: 10.1016/00431648(95)07171-7

14. Galusek D, Twigg PC, Riley FL. Wet erosion of liquid phase sintered alumina. Wear. 1999;233-235:588-595. DOI: 10.1016/ S0043-1648(99)00236-7

15. Krell A, Blank P, Ma H, Hutzler T, Nebelung M. Processing of High-Density Submicrometer Al2O 3 for New Applications. Journal of the American Ceramic Society. 2003;86(4):546-553. DOI: 10.1111/j.1151-2916.2003.tb03339.x

16. Roy RS, Guchhait H, Chanda A, Basu D, Mitra MK. Improved sliding wear-resistance of alumina with sub-micron grain size: A comparison with coarser grained material. Journal of the European Ceramic Society. 2007;27(16):4737-4743. DOI: 10.1016/j.jeurceramsoc.2007.02.205

17. Hsu YF, Wang SF, Wang YR, Chen SC. Effect of niobium doping on the densification and grain growth in alumina. Ceramics International. 2008;34(5):1183-1187. DOI: 10.1016/j. ceramint.2007.02.010

18. Wu Y, Zhang Y, Choy KL, Guo J. Liquid-phase sintering of alumina with YSiAlON oxynitride glass. Materials Letters. 2003;57(22-23):3521-3525. DOI: 10.1016/S0167-577X(03)00119-8

19. Montedo ORK, Milak PC, Minatto FD, Nuernberg RB, Faller CA, Oliveira APN, et al. Effect of a LZSA glass-ceramic addition on the sintering behavior of alumina. Journal of Thermal Analysis and Calorimetry. 2016;124(1):241-249. DOI: $10.1007 / \mathrm{s} 10973-015-5144-5$

20. Montedo ORK, Bertan FM, Piccoli R, Hotza D, Klein AN, Oliveira APN. Low thermal expansion sintered LZSA glassceramics. American Ceramic Society Bulletin. 2008;87:34-38.

21. Montedo ORK, Floriano FJ, de Oliveira Filho J, Angioletto E, Bernardin AM. Sintering behavior of LZSA glass-ceramics. Materials Research. 2009;12(2):197-200. DOI: 10.1590/ S1516-14392009000200014

22. Montedo ORK, Floriano FJ, de Oliveira Filho J. Sintering kinetics of a $18.8 \mathrm{Li}_{2} \mathrm{O} 8.3 \mathrm{ZrO}_{2} 64.2 \mathrm{SiO}_{2} 8.7 \mathrm{Al}_{2} \mathrm{O}_{3}$ glass ceramic. Ceramics International. 2011;37(6):1865-1871. DOI: $10.1016 / \mathrm{j}$. ceramint.2011.03.047

23. Montedo ORK, Oliveira APN. Relationship between Surface Abrasion Wear and Brightness in Glazed Porcelainized Stoneware Tiles. ISRN Ceramics. 2011;2011:548129. DOI: $10.5402 / 2011 / 548129$

24. Montedo ORK, Hotza D, Oliveira APN, Meszaros R, Travitzky N, Greil P. Crystallisation Kinetics of a B-Spodumene-Based Glass Ceramic. Advances in Materials Science and Engineering. 2012;2012:525428. DOI: 10.1155/2012/525428

25. Montedo ORK, Milak PC, Faller CA, Peterson M, Angioletto E, De Noni A Jr. Effect of LZSA Glass-Ceramic Addition on the Pressureless Sintered Alumina. Part I: Grain Growth. Materials Research. 2017;20(4):1024-1028. DOI: 10.1590/1980-5373mr-2016-0964

26. Terheci M. Grain boundary and testing procedure, a new approach to the tribology of alumina materials. Wear. 1997;211(2):289301. DOI: 10.1016/S0043-1648(07)00133-0 
27. Munro M. Evaluated Material Properties for a Sintered alpha-Alumina. Journal of the American Ceramic Society. 1997;80(8):1919-1928. DOI: 10.1111/j.1151-2916.1997. tb03074.x

28. Lube T, Pascual J, Chalvet F, Portu G. Effective fracture toughness in $\mathrm{Al}_{2} \mathrm{O}_{3}-\mathrm{Al}_{2} \mathrm{O}_{3} / \mathrm{ZrO}_{2}$ laminates. Journal of the European Ceramic Society. 2007;27(2-3):1449-1453. DOI: $10.1016 /$ j.jeurceramsoc.2006.04.063

29. Marques CM. Relação entre microestrutura e desgaste erosivo a frio e a quente em materiais cerâmicos à base de alumina. $[\mathrm{PhD}$ Thesis]. Porto Alegre: Universidade Federal do Rio Grande do Sul; 2006.

30. Tuan WH, Lai MJ, Lin MC, Chan CC, Chiu SC. The mechanical performance of alumina as a function of grain size. Materials Chemistry and Physics. 1994;36(3-4):246-251. DOI: 10.1016/02540584(94)90037-X

31. National Institute of Standards and Technology - NIST. Available from: <http://www.nist.gov/>. Access in: 04/10/2017.

32. Binns DB, Popper P. Mechanical Properties of Some Commercial Alumina Ceramics. Proceedings of the British Ceramic Society. 1966;122:71-82.

33. Sathiyakumar M, Gnanam FD. Role of wollastonite additive on density, microstructure and mechanical properties of alumina. Ceramics International. 2003;29(8):869-873. DOI: 10.1016/ S0272-8842(03)00029-4
34. Goswami AP, Das GC. Role of fabrication route and sintering on wear and mechanical properties of liquid-phase-sintered alumina. Ceramics International. 2000;26(8):807-819. DOI: $10.1016 / \mathrm{S} 0272-8842(00) 00022-5$

35. De Noni A Jr., Hotza D, Soler VC, Vilches ES. Influence of composition on mechanical behaviour of porcelain tile. Part III: Effect of the cooling rate of the firing cycle. Materials Science and Engineering: A. 2011;528(9):3330-3336. DOI: 10.1016/j. msea.2010.12.086

36. Goswami AP, Roy S, Mitra MK, Das GC. Influence of powder, chemistry and intergranular phases on the wear resistance of liquid-phase-sintered $\mathrm{Al}_{2} \mathrm{O}_{3}$. Wear. 2000;244(1-2):1-14. DOI: 10.1016/S0043-1648(00)00407-5

37. Goswami AP, Roy S, Mitra MK, Das GC. Microstructure dependent hardness and fracture behavior in liquid-phasesintered $\mathrm{Al}_{2} \mathrm{O}_{3}$. Ceramics International. 2000;26(4):397-410. DOI: $10.1016 / \mathrm{S} 0272-8842(99) 00070-\mathrm{X}$

38. Goswami AP, Roy S, Mitra MK, Das GC. Impurity-Dependent Morphology and Grain Growth in Liquid-Phase-Sintered Alumina. Journal of the American Ceramic Society. 2001;84(7):16201626. DOI: $10.1111 / \mathrm{j} .1151-2916.2001 . t b 00886 . x$ 